\title{
Expression of Podoplanin and Classical Cadherins in Salivary Gland Epithelial Cells of Klotho-Deficient Mice
}

\author{
Ikuko Amano $^{1}$, Yuri Imaizumi ${ }^{1}$, Chiaki Kaji ${ }^{1}$, Hiroshi Kojima ${ }^{1}$ and Yoshihiko Sawa ${ }^{2}$ \\ ${ }^{1}$ Department of Oral Growth \& Development, Fukuoka Dental College, Japan and ${ }^{2}$ Department of Morphological Biology, Fukuoka \\ Dental College, Japan
}

Received August 3, 2011; accepted September 21, 2011; published online November 5, 2011

\begin{abstract}
We have recently shown that salivary gland myoepithelial cells express podoplanin. Podoplanin indirectly binds the actin filament network which links classical cadherins. The study here is aimed to investigate the expression of podoplanin and cadherins on salivary gland myoepithelial cells and the changes in the aging cells using klotho-deficient (kl/kl) mice. The submandibular glands of $\mathrm{kl} / \mathrm{kl}$ mouse lack granular ducts which express klotho in wild type mice, suggesting that klotho may be a gene responsible for granular duct development. Although aging resulted in growth suppression of myoepithelial cells because of the sparse distribution of the cells in $\mathrm{kl} / \mathrm{kl}$ mouse salivary glands, the expression of podoplanin and $\mathrm{E}$ cadherin was shown in aging myoepithelial cells. It is thought that podoplanin participates in the actin-E-cadherin networks which are maintained in aging myoepithelial cells. It was also shown that granular ducts were filled with P-cadherin, and that the P-cadherin amount was larger in the wild type mouse submandibular glands than in the sublingual and parotid glands of wild type mouse, and in the submandibular glands of $\mathrm{kl} / \mathrm{kl}$ mouse. These findings suggest that the granular duct is an organ secreting soluble P-cadherin into the saliva.
\end{abstract}

Key words: podoplanin, P-cadherin, N-cadherin, klotho, salivary gland

\section{Introduction}

Podoplanin is a mucin-type transmembrane glycoprotein first identified in kidney glomerular epithelial cells, the podocytes [5]. It has been thought that podoplanin plays a role in maintaining the shape of podocyte foot processes and glomerular permeability [30]. Podoplanin is also well known as a lymphatic endothelial cell marker [46]. The podoplanin-deficient mice have defects in lymphatic formation but not in blood vessels. The podoplanin promoter region lacks the TATA and CAT box but has a $\mathrm{CpG}$ island with putative Spl and AP-4 sites [17]. Such promoters are usually present at the 5'-flanking region of housekeeping genes and $\mathrm{CpG}$ hypermethylation has been linked with their transcriptional repression [17]. Nonetheless, podoplanin expression is limited to certain somatic cells. The DNA

Correspondence to: Yoshihiko Sawa, Department of Morphological Biology, Fukuoka Dental College, 2-15-1 Tamura, Sawara-ku, Fukuoka 814-0193, Japan. E-mail: ysawa@college.fdcnet.ac.jp methyltransferase inhibitor reduces podoplanin mRNA in podoplanin highly expressing osteosarcoma MG63 cells having CpG hypermethylation but has no effect in podoplanin low expressing osteosarcoma Saos-2 cells without CpG methylation [17]. Therefore, it has been thought that there is $\mathrm{CpG}$ methylation-dependent podoplanin transcription enhancement based on chromatin structure modifications [17, 43, 51]. Podoplanin up-regulates a Ras homolog gene family member A (RhoA)-GTPase activity resulting in ezrin phosphorylation [37]. Podoplanin links and stabilizes the phosphorylated ezrin mediating an anchorage of F-actin to the plasma membrane $[3,9,33]$. The increase in cell surface distribution of phosphorylated ezrin promotes the actin cytoskeleton rearrangement by the development of membrane-actin structures [3, 9, 33]. Therefore, podoplanin finally promotes a rearrangement of the actin filament network by RhoA activation. The actin filament network links classical cadherins through cytoplasmic $\alpha$ - and $\beta$ catenin [1, 34]. Classical cadherins are single-span transmembrane proteins and carry the calcium-dependent cell- 
cell adhesion through five extracellular calcium binding repeats from apposed cells located primarily within adherens junctions. Classical cadherins play a basic role in cell recognition during embryogenesis, during which specific expression patterns mark specific cell types and tissues [16].

The klotho-deficient $(\mathrm{kl} / \mathrm{kl})$ mouse is known as an animal model that prematurely shows phenotypes resembling human aging and age-associated diseases triggered by klotho gene deficiency $[32,36]$. The klotho gene deficiency is caused by the insertion of ectopic DNA containing the rabbit type I $\mathrm{Na}^{+}-\mathrm{H}^{+}$exchanger into the $5^{\prime}$ promoter region of the klotho gene, resulting in the hardly expressed $\alpha$-klotho protein. Klotho protein acts as a calcium regulator which transports $\mathrm{Na}^{+}, \mathrm{K}^{+}$-ATPase from intracellular organelles to the cell surface. Although $\mathrm{kl} / \mathrm{kl}$ mice appear normal at birth, they show multiple age-associated disorders, such as arteriosclerosis, osteopolosis, skin atrophy, depletion of Purkinje cells in the cerebellum, and infertility at 3-4 weeks of age. The $\mathrm{kl} / \mathrm{kl}$ mice die at around 2 months of age whereas wild type mice live for approximately 3 years. The symptoms of aging in $\mathrm{kl} / \mathrm{kl}$ mice indicate that klotho protein contributes to a suppression of aging $[32,36]$.

We have recently shown that tooth germ epithelium and salivary gland myoepithelium express podoplanin [19, $20,23,25,39,45]$. In particular, immunohistochemistry on salivary glands showed that the surfaces of both the mucous acini terminal portion and ducts are covered by extensive myoepithelial cellular processes expressing podoplanin. Further, in an immunoelectron microscopy, a number of reaction products with anti-podoplanin antibody were present at the Golgi apparatus binding to the endoplasmic reticulum in myoepithelial cell cytoplasm, and at the cell membrane [20]. Since it has been established that podoplanin indirectly binds the actin filament which links classical cadherins $[3,9,33,37,51]$, it may be expected that the podoplanin participates in the actin filament networks which link classical cadherins of myoepithelial cells. However, there has been no report on the relation of podoplanin and cadherin expressions in salivary gland myoepithelial cells. This study aimed to investigate the distribution of myoepithelial cells expressing podoplanin and classical cadherins in mouse salivary glands and its change with aging.

\section{Materials and Methods}

\section{Immunohistochemistry}

This study used tissues of parotid, submandibular, and sublingual glands, and of tongue and testis of seven-weekold male $\mathrm{kl} / \mathrm{kl}$ mice and the wild type mice $(\mathrm{n}=5)$ (klotho/ Jcl, CLEA Japan, Inc., Tokyo, Japan), and the tissue of mammary gland tissue of nine-week-old female ICR mice with lactating $(n=5)$ (CLEA Japan). The tissue was collected after euthanasia by intraperitoneal injection with sodium pentobarbital $(10 \mathrm{ml} / \mathrm{kg}$, Nembutal, Abbott Laboratories, North Chicago, IL). The protocol for animal use was reviewed and approved by the animal experiment committee of Fukuoka Dental College in accordance with the principles of the Helsinki Declaration. Frozen $10 \mu \mathrm{m}$ sections were cut in a cryostat and fixed in $100 \%$ methanol for $10 \mathrm{~min}$ at $-20^{\circ} \mathrm{C}$. The sections were treated with $0.1 \%$ goat or rabbit serum for $30 \mathrm{~min}$ at $20^{\circ} \mathrm{C}$ and then the sections were treated with $0.5 \mu \mathrm{g} / \mathrm{ml}$ of antibodies: monoclonal hamster anti-mouse podoplanin (AngioBio Co., Del Mar, $\mathrm{CA}$ ), polyclonal rabbit anti-mouse $\alpha$-smooth muscle actin ( $\alpha$-SMA) (Epitomics, Burlingame, $\mathrm{CA}$ ), monoclonal rat anti-mouse P-cadherin (R\&D Systems Inc., Minneapolis, $\mathrm{MN}$ ), monoclonal rat anti-mouse E-cadherin (R\&D Systems), polyclonal rabbit anti-mouse $\mathrm{N}$-cadherin (Abcam, Cambridge, UK), polyclonal rabbit anti-mouse VE-cadherin (Abcam), and polyclonal goat anti-klotho peptide (LifeSpan Biosciences, Inc. Seattle, WA), for $8 \mathrm{hr}$ at $4^{\circ} \mathrm{C}$. After the treatment with first antibodies the sections were immunostained for $0.5 \mathrm{hr}$ at $20^{\circ} \mathrm{C}$ with $0.1 \mu \mathrm{g} / \mathrm{ml}$ of second antibodies: Alexa Fluor (AF) 488 or 568-conjugated goat antihamster, goat anti-rabbit, goat anti-rat, rabbit anti-goat, or rabbit anti-rat IgGs (Invitrogen, Eugene, OR). The immunostained sections were examined by fluorescence microscopy BZ-8100 (Keyence Corp., Osaka, Japan) or laser-scanning microscopy (LSM710, Carl Zeiss, Jena, Germany) with a PlanApochromatic $60 \times$ oil immersion objective lens (numerical aperture $\times 1.3$ ).

\section{Reverse transcription (RT)-PCR and real-time PCR}

The total RNA extraction from tissue of the parotid, submandibular, and sublingual glands of wild type mice, and the submandibular glands of $\mathrm{kl} / \mathrm{kl}$ mice was achieved with a QIAshredder column and RNeasy kit (Qiagen, Inc., Tokyo, Japan). Contaminating genomic DNA was removed using DNAfree (Ambion, Huntingdon, UK), and the RT was performed on $30 \mathrm{ng}$ of total RNA, followed by 25-30 cycles of PCR for amplification using the Ex Taq hot start version (Takara Bio Inc., Otsu, Japan) with 50 pM of primer sets: mouse $\beta$-actin (forward, 5'-GTTCTACAAATGTGGCTG AGGA; reverse, 5'-ATTGGTCTCAAGTCAGTGTACAG, $411 \mathrm{bp}$ ), and mouse P-cadherin (forward, 5'-GCAGAAG TCAGCGAGAAAGGAG; reverse, 5'-GGAGGATGAAA CCACCCTTCCA, 199 bp) where the specificities had been confirmed by the manufacturer (Sigma-Genosys Ltd., Cambridge, UK). The RT-PCR products were separated on $2 \%$ agarose gel (NuSieve; FMC, Rockland, ME, USA) and visualized by Syber Green (Takara). The correct size of the amplified PCR products was confirmed by gel electrophoresis and amplification of accurate targets was confirmed by sequence analysis.

To quantify P-cadherin mRNA generation, cDNA samples were analyzed by real-time quantitative PCR. A total of $1 \mu \mathrm{l}$ of cDNA was amplified in $25 \mu \mathrm{l}$ using PowerSYBR Green PCR Master Mix (Applied Biosystems, Foster City, CA, USA) in a Stratagene Mx3000P real-time PCR system (Agilent Technologies, Inc., Santa Clara, CA, USA), and the fluorescence was monitored at each cycle. Cycle parameters were $95^{\circ} \mathrm{C}$ for $15 \mathrm{~min}$ to activate Taq followed by 35 cycles of $95^{\circ} \mathrm{C}$ for $15 \mathrm{sec}, 58^{\circ} \mathrm{C}$ for $1 \mathrm{~min}$, and $72^{\circ} \mathrm{C}$ for $1 \mathrm{~min}$. For real-time analysis, two standard 
curves were constructed from amplicons for both $\beta$-actin and P-cadherin in three serial 4-fold dilutions of cDNA from sublingual gland tissue. The $\beta$-actin or P-cadherin cDNA levels in each sample were quantified against $\beta$-actin or Pcadherin standard curves by allowing the Mx3000P software to accurately determine each cDNA unit. Finally, P-cadherin cDNA units in each sample were normalized to $\beta$-actin cDNA units. The relative P-cadherin gene expression units were expressed as arbitrary units, calculated according to the following formula: relative $\mathrm{P}$-cadherin gene expression units $=\mathrm{P}$-cadherin cDNA units $/ \beta$-actin cDNA units.

\section{Western blot}

Tissues of the parotid, submandibular, and sublingual glands of wild type mice, submandibular gland of $\mathrm{kl} / \mathrm{kl}$ mice, and mammary gland of female ICR mice with lactating were solubilized in $1 \mathrm{ml}$ of cell lysis buffer (Cell Signaling Technology, Inc., Danvers, MA). The lysate of whole cell protein $(1 \mathrm{mg} / \mathrm{ml})$ was mixed with an equal volume of sample buffer (Bio-Rad Laboratories Inc., Hercules, CA). A 20$\mu \mathrm{l}$ volume of sample was loaded on $15 \%$ polyacrylamide gel by electrophoresis with Mini-protean III (Bio-Rad), and the separated proteins were transferred onto a PVDF membrane (Invitrogen Life Technologies, Carlsbad, CA). After blocking of the PVDF membrane by $0.1 \%$ goat serum for $2 \mathrm{hr}$ at $20^{\circ} \mathrm{C}$, the membrane was treated with monoclonal rat anti-mouse P-cadherin (R\&D) and with $1 \mathrm{ng} / \mathrm{ml}$ of peroxidase-conjugated goat anti-rat $\mathrm{IgG}$, and then visualized by the substrate of Vector Elite ABC kit and Vector VIP kit (Vector Laboratories, Burlingame, CA) or ImmunStar WesternC Chemiluminescence kit (Bio-Rad), and scanned by the image analyzer LAS-3000 mini (Fujifilm Corp., Tokyo, Japan).

\section{Statistics}

All experiments were carried out five times, repeatedly, and data are expressed as mean \pm SEM. The statistical sig- nificance of differences $(\mathrm{p}<0.001)$ was determined by oneway ANOVA with STATVIEW 4.51 software (Abacus Concepts, Calabasas, CA, USA).

\section{Results}

\section{Immunohistochemical examination on klotho and myoepithelial markers in mouse salivary glands}

The size of body and submandibular glands are significantly smaller in $\mathrm{kl} / \mathrm{kl}$ mice than in wild type mice at seven weeks after birth (Fig. 1). In the immunohistochemistry for the mouse tissue, lingual blood vessels were immunostained with anti- $\alpha$-SMA without cross reaction to lingual mucous epithelia or intrinsic lingual muscle. An antiE-cadherin reacted with lingual mucous epithelium at cellcell contacts and an anti-P-cadherin reacted with mammary gland epithelia and milk (Fig. 2). In the immunostaining for podoplanin and $\alpha$-SMA on the submandibular glands, myoepithelial cells around acini and ducts were stained with both anti-podoplanin and anti- $\alpha$-SMA. In the $\mathrm{kl} / \mathrm{kl}$ mice, there were no granular ducts and the size of acini was significantly smaller than in wild type mice. The region of myoepithelial cells immunostained by both anti-podoplanin and anti- $\alpha$-SMA around acini and on the basal side of ducts was smaller and more sparsely in the submandibular gland lobule of $\mathrm{kl} / \mathrm{kl}$ mice than in the wild type mice (Fig. 3). Further, there were many portions stained with anti- $\alpha$-SMA but not with anti-podoplanin in the acini, ducts, and blood vessels of submandibular gland (Fig. 3). In the immunostaining for klotho protein on the wild type mouse testis and major salivary glands, reaction products with anti-klotho were found on Sertoli nursing cells, spermatid, and spermatogonia, and only granular ducts were stained with antiklotho on the basal side of duct cells while acini, and striated, intercalated, and intralobular ducts were not stained with anti-klotho in any of the salivary glands (Fig. 4).

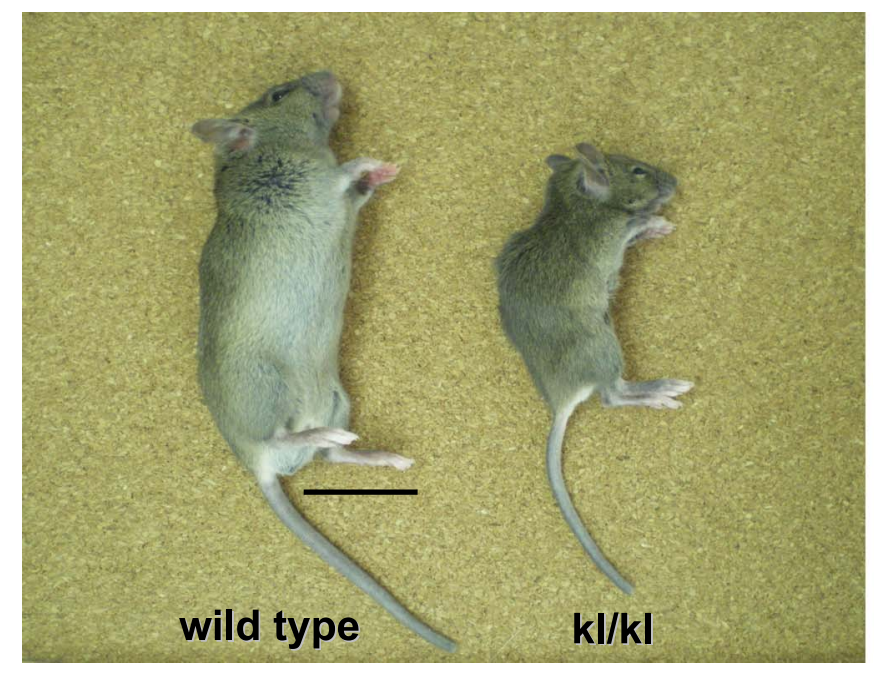

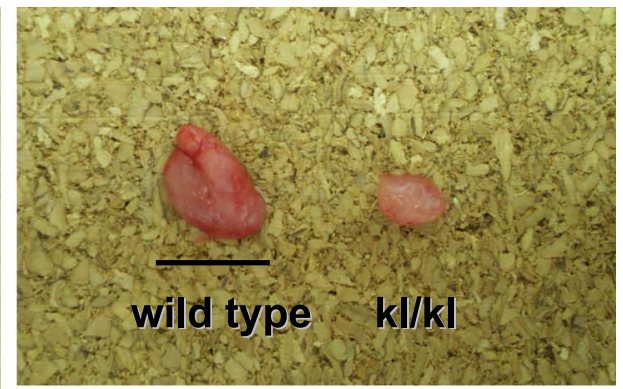

submandibular gland

Fig. 1. Macroscopic differences of submandibular glands between $\mathrm{kl} / \mathrm{kl}$ and the wild type mice. Size of body and submandibular glands are significantly smaller in the $\mathrm{kl} / \mathrm{kl}$ mice than in wild type mice at seven weeks after birth. Bar=25 mm (left) and $10 \mathrm{~mm}$ (right). 

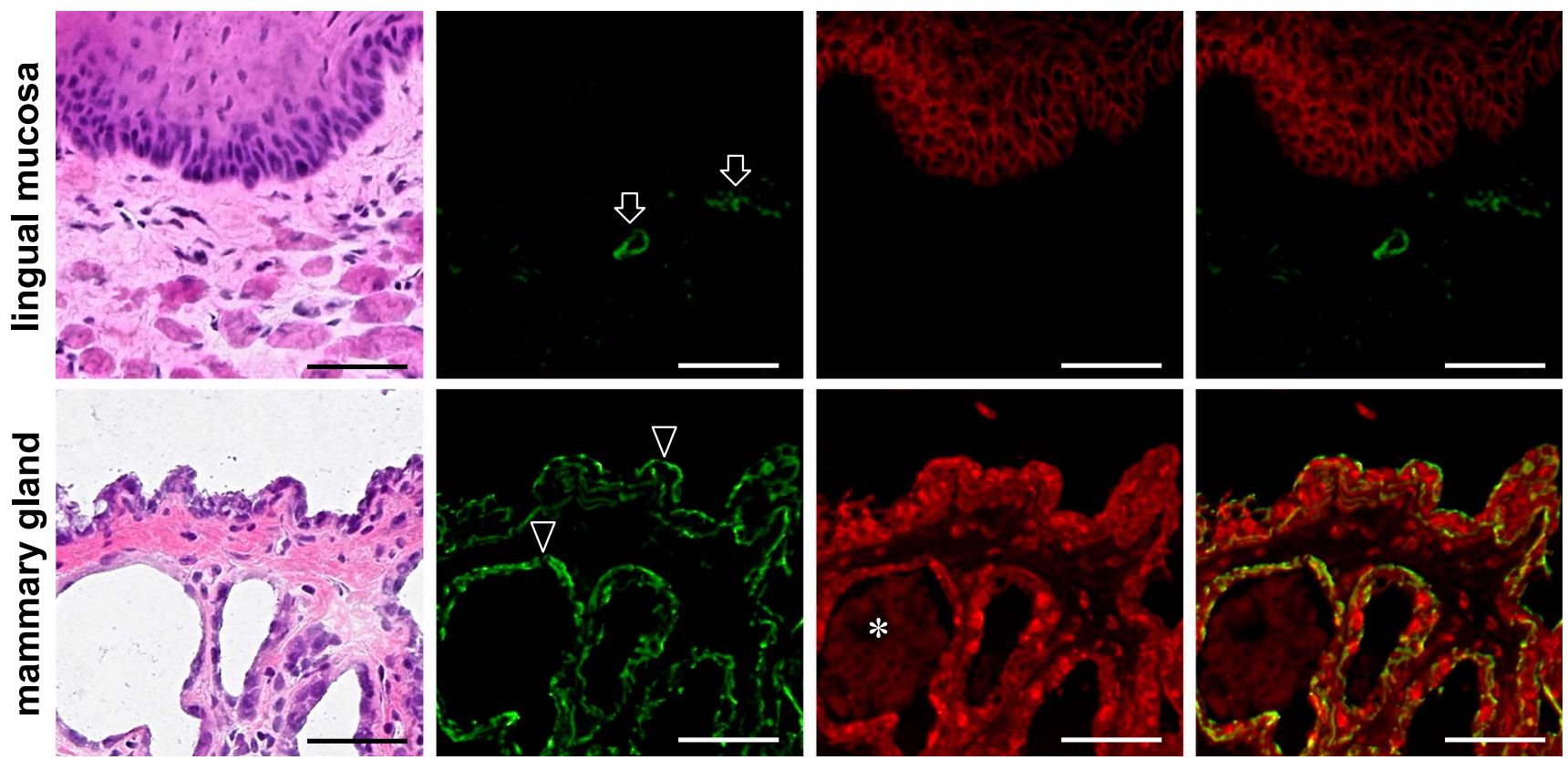

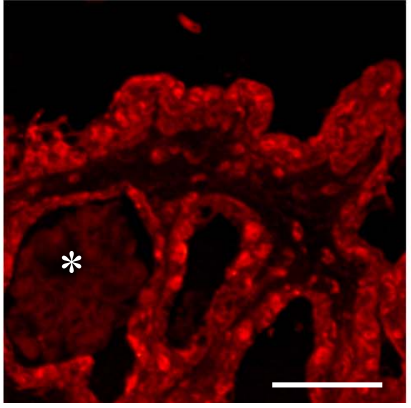

E-/P-cadherin

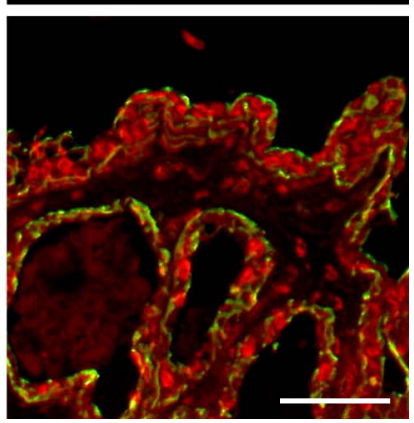

Merge

Fig. 2. Immunostaining for $\alpha$-SMA, and E-/P-cadherins of mouse tongue and breast. The H-E staining shows the lingual mucosa and mammary gland with lactating. Reaction products with anti- $\alpha$-SMA are observed on blood vessels in tunica muscularis (arrows) and on mammary gland epithelia (arrowheads), whereas no cross reaction is observed on the lingual mucous epithelia and the intrinsic lingual muscle. Reaction products with anti-E-cadherin (upper figure) are observed on the lingual mucous epithelia at cell-cell contacts with no cross reaction in the tunica muscularis. Reaction products with anti-P-cadherin (lower figure) are observed on mammary gland epithelia as well as on milk in the latex ducts (asterisk). Bar=100 $\mu \mathrm{m}$.

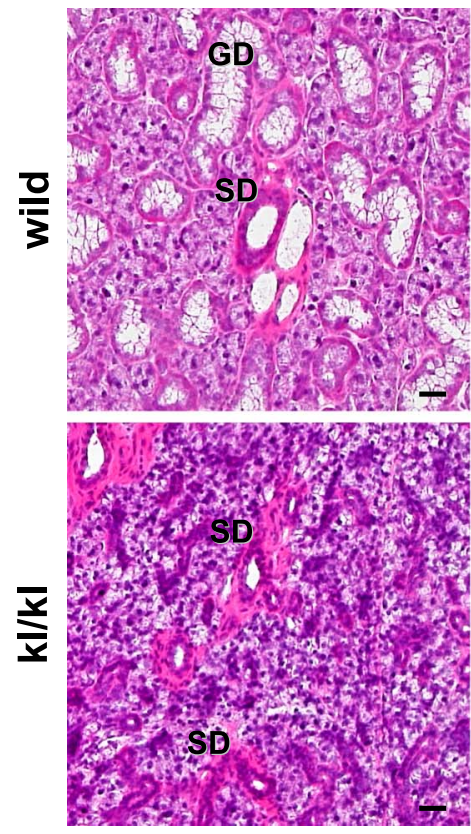

H-E
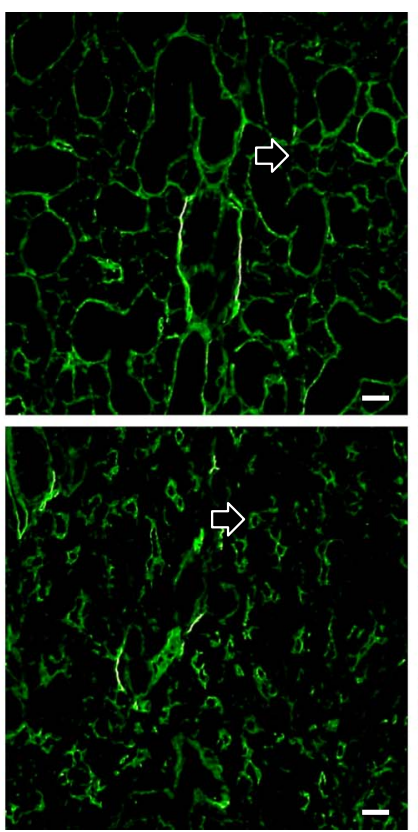

podoplanin
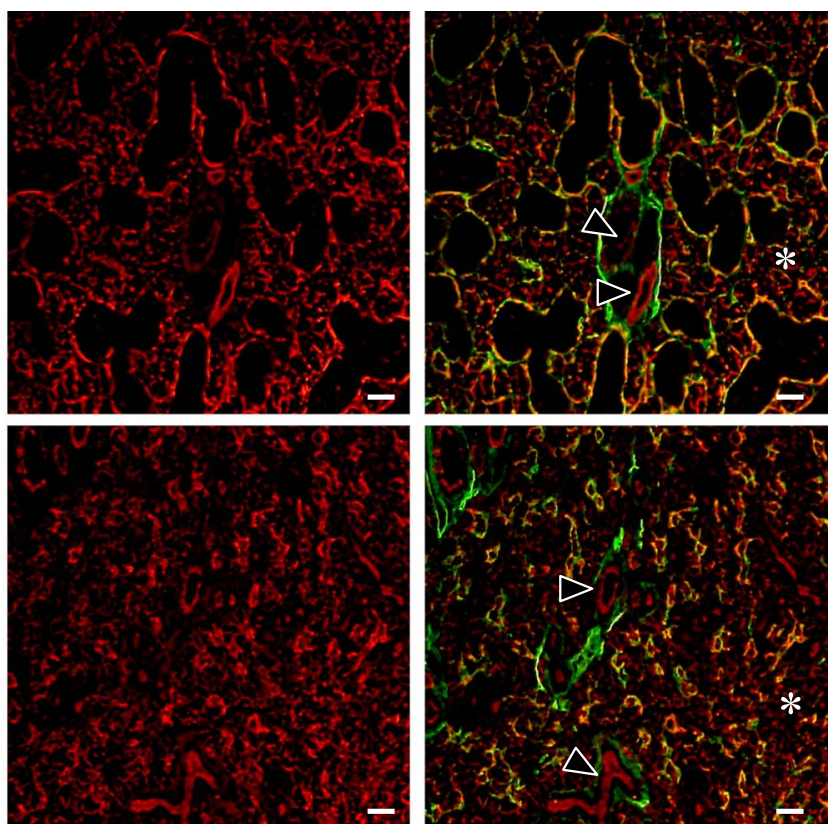

$\alpha$-SMA

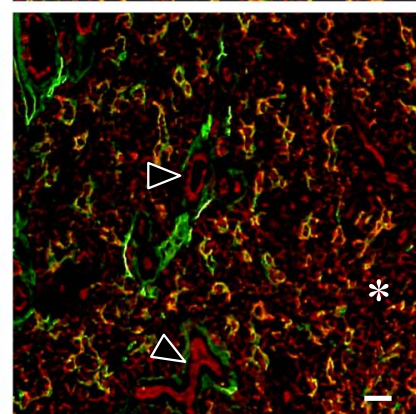

Merge

Fig. 3. Immunostaining for podoplanin and $\alpha$-SMA of mouse submandibular glands. The H-E staining shows that terminal secretory end pieces are composed of seromucous acinar cells with basophilic cytoplasm, and that striated ducts (SD) are composed of columnar cells with acidopilic cytoplasm in both $\mathrm{kl} / \mathrm{kl}$ mice and wild type mice. In $\mathrm{kl} / \mathrm{kl}$ mice, there are no granular ducts (GD) and the size of acini is significantly smaller than in wild type mice at seven weeks of age. The region of myoepithelial cells around acini and the basal side of ducts, which reacted with both anti-podoplanin and anti- $\alpha$-SMA, is smaller and more sparsely in the submandibular gland lobule of kl/kl mice than in the wild type mice (arrows). More regions are immunostained with anti- $\alpha$-SMA than with anti-podoplanin in both $\mathrm{kl} / \mathrm{kl}$ mice and the wild type mice. The inside of acinar cells (asterisks) and the luminal side of striated ducts (arrowheads), and blood vessel walls (arrowhead) are reacted with anti- $\alpha$-SMA, but not with anti-podoplanin. Bar=100 $\mu \mathrm{m}$. 

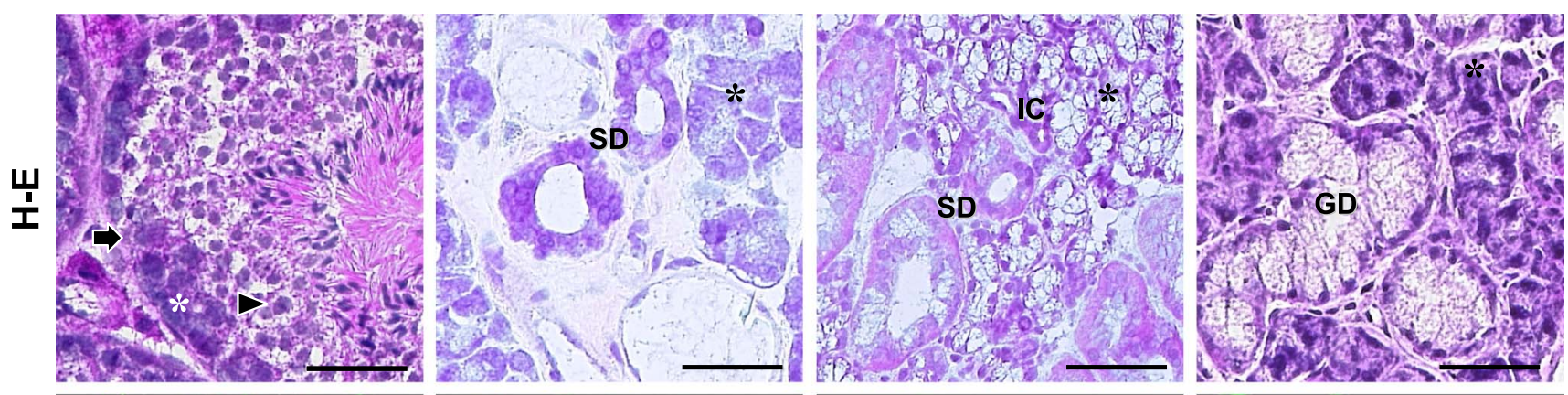

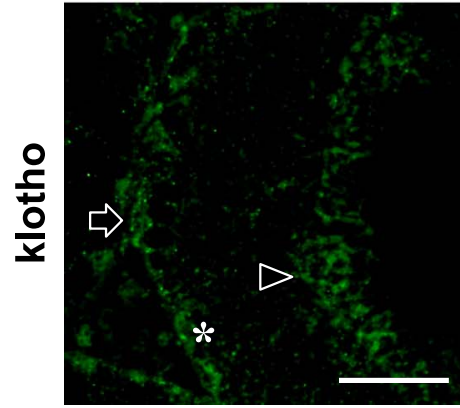

testis

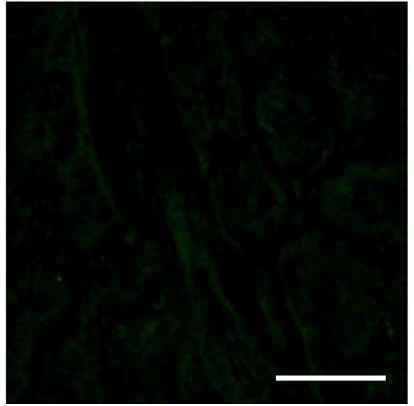

parotid gland

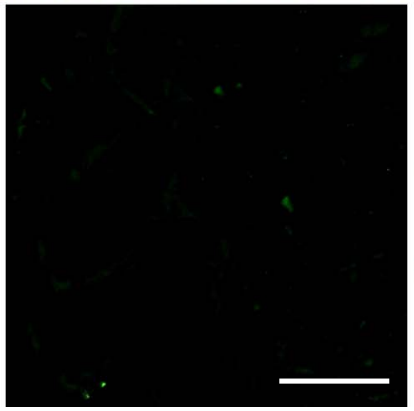

sublingual gland

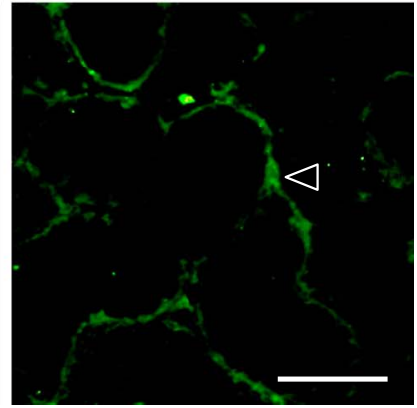

submandibular gland

Fig. 4. Immunostaining for klotho protein on mouse testis and major salivary glands. The H-E staining shows testis and acini of the three major salivary glands of wild type mice. In the testis reaction products with anti-klotho are found on Sertoli nursing cells (arrows), spermatid (arrowheads), and spermatogonia (asterisks). Reaction products with anti-klotho are not found on acinar cells in any of the salivary glands (asterisks). Reaction products with anti-klotho are also not found on striated ducts (SD) with acidopillic cytoplasm, and on intercalated ducts (IC), having a narrow lumen surrounded by cuboidal cells, but are found on a basal side of granular ducts (GD) (arrowhead). Bar=100 $\mu \mathrm{m}$.
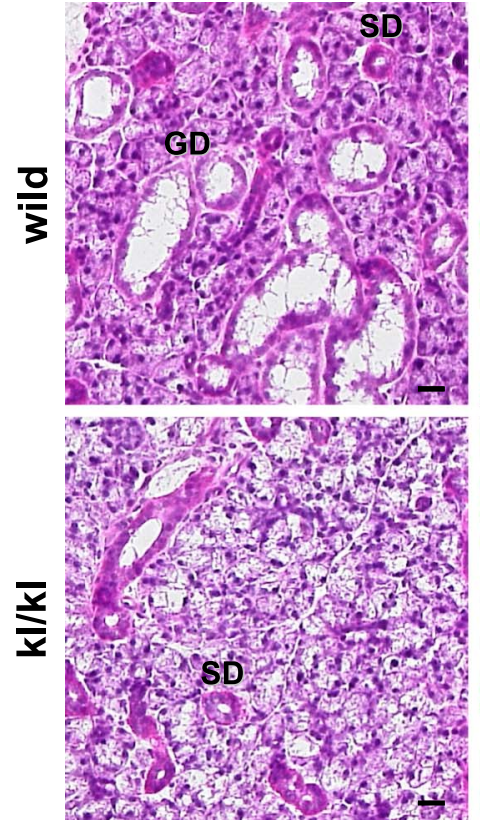

H-E
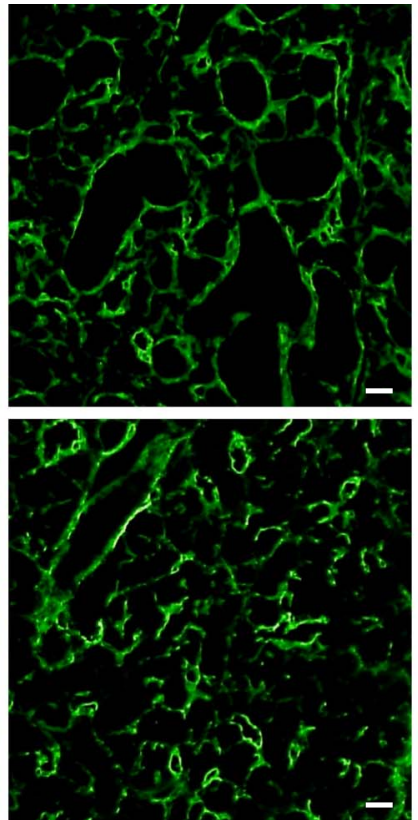

podoplanin
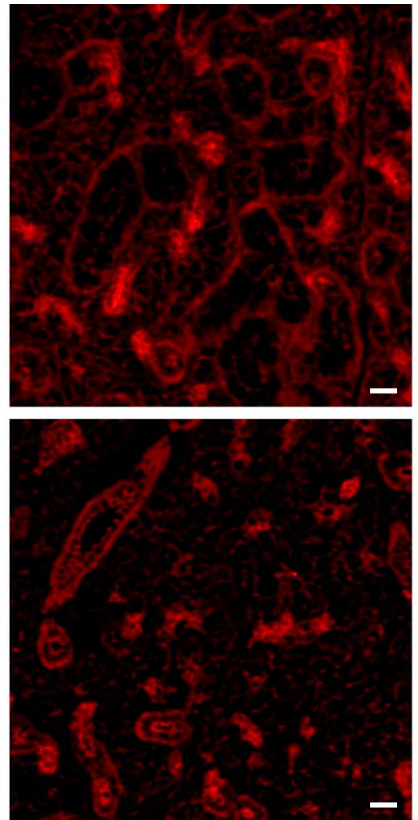

E-cadherin
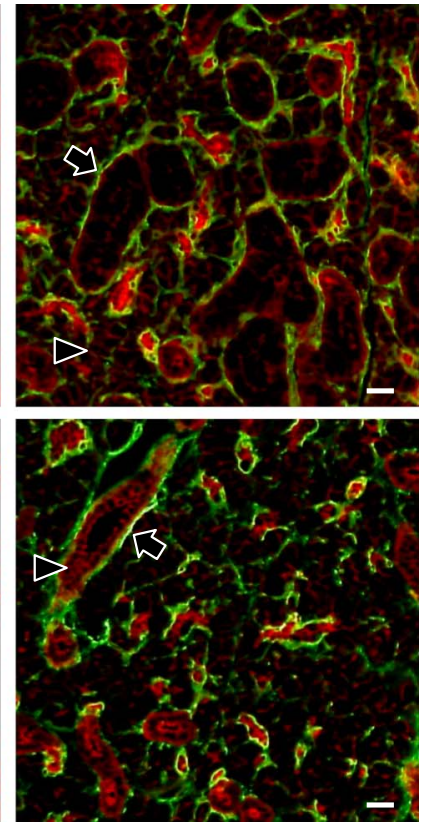

Merge

Fig. 5. Immunostaining for podoplanin and E-cadherin of submandibular glands. The H-E staining shows terminal seromucous acini and striated ducts (SD) in $\mathrm{kl} / \mathrm{kl}$ and wild type mice, and granular ducts (GD) in wild type mice. The region of myoepithelial cells around acini and ducts was immunostained with anti-podoplanin, and with anti-E-cadherin in both $\mathrm{kl} / \mathrm{kl}$ and wild type mice (arrows). Epithelial cells of acini and ducts were also stained with anti-E-cadherin at cell-cell contacts where reaction products with anti-podoplanin were not found in $\mathrm{kl} / \mathrm{kl}$ or wild type mice (arrowheads). Bar $=100 \mu \mathrm{m}$. 

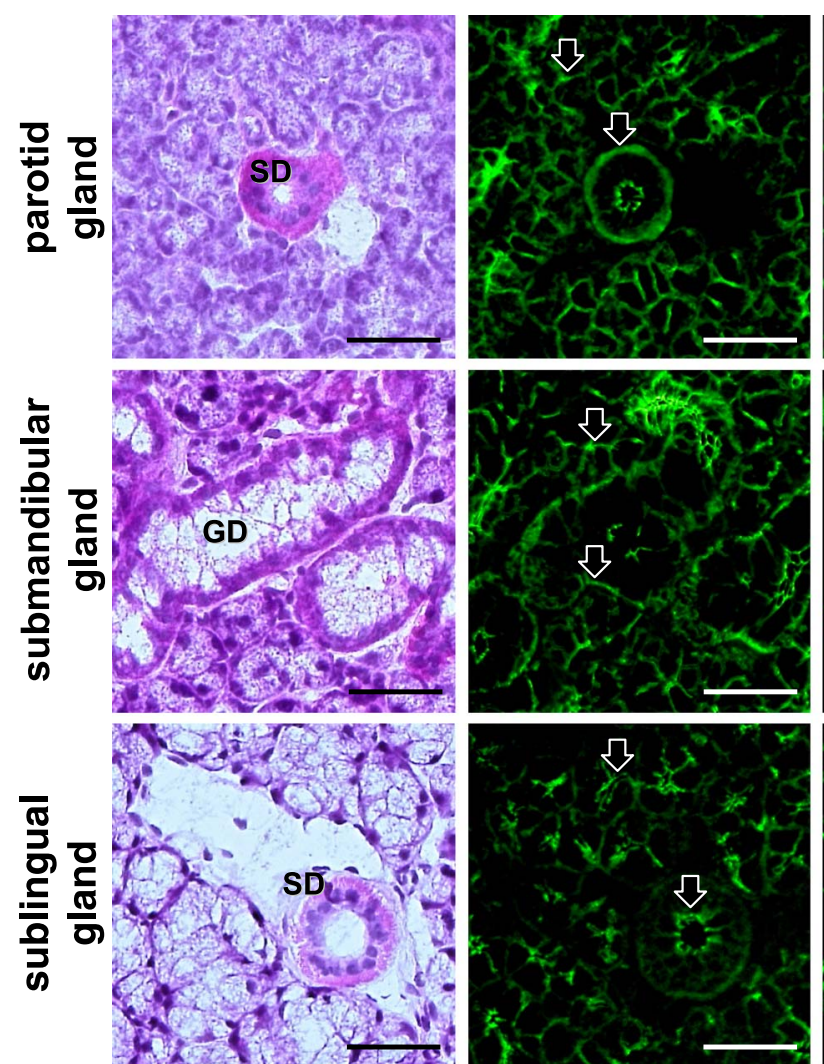

H-E
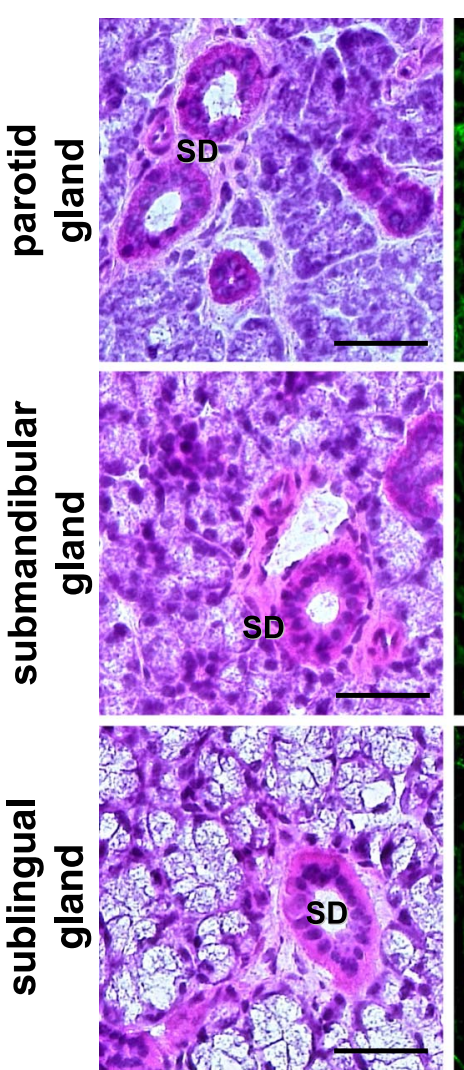

H-E
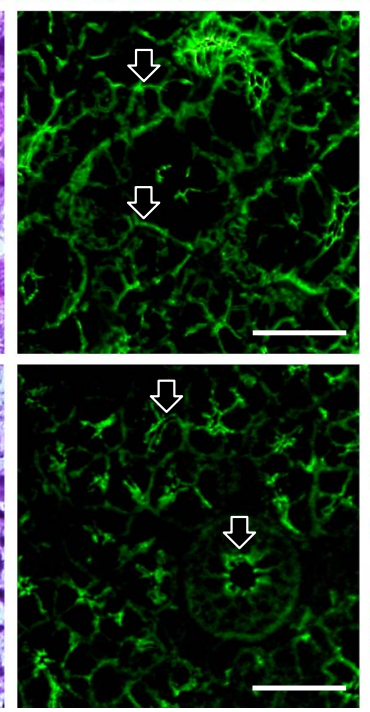

E-cadherin
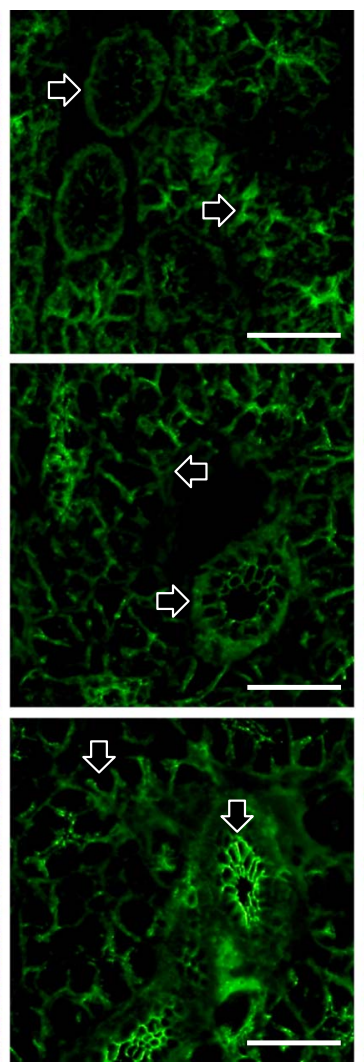

E-cadherin
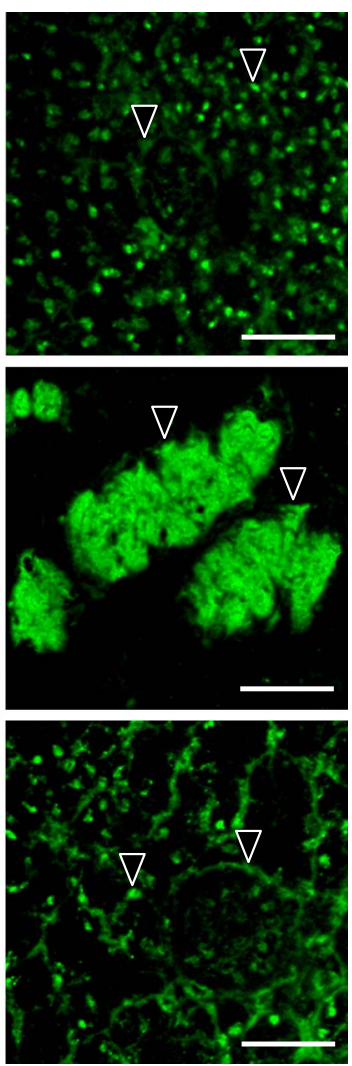

P-cadheirn
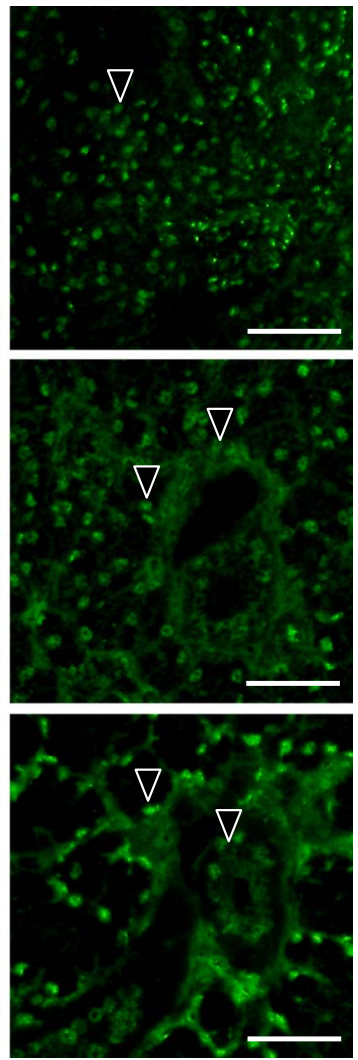

P-cadheirn
Fig. 6. Immunostaining of E-cadherin and $\mathrm{P}$-cadherin in mouse major salivary glands of wild type mice. The H-E staining shows that the parotid gland of which terminal secretory end pieces of acini are composed of serous pyramidal cells and the striated duct (SD) are composed of columnar cells with acidopillic cytoplasm, the submandibular gland with basophilic seromucous acinar cells and granular ducts (GD), and the sublingual gland of which terminal secretory end pieces are composed of mucous-filled acinar cells. In all salivary glands, reaction products with anti-Ecadherin (arrows) are found at the area of myoepithelial cells around acini and ducts, and at cell-cell contacts of epithelial cells of acini and ducts. Reaction products with anti-P-cadherin (arrowheads) are found in nuclei, and around acini and ducts weakly in both parotid and sublingual glands while in the submandibular gland, granular ducts (GD) are filled with strong reaction products with anti-P-cadherin (arrowheads). $\mathrm{Bar}=100 \mu \mathrm{m}$.
Fig. 7. Immunostaining of E-cadherin and P-cadherin in mouse major salivary glands of $\mathrm{kl} / \mathrm{kl}$ mice. Reaction products with antiE-cadherin (arrows) are found at the area of myoepithelial cells around acini and ducts, and at cell-cell contacts of epithelial cells of acini and striated ducts (SD) whereas reaction products with anti-Pcadherin are found in nuclei, and around acini and ducts weakly (arrowheads). Bar= $100 \mu \mathrm{m}$. 
A

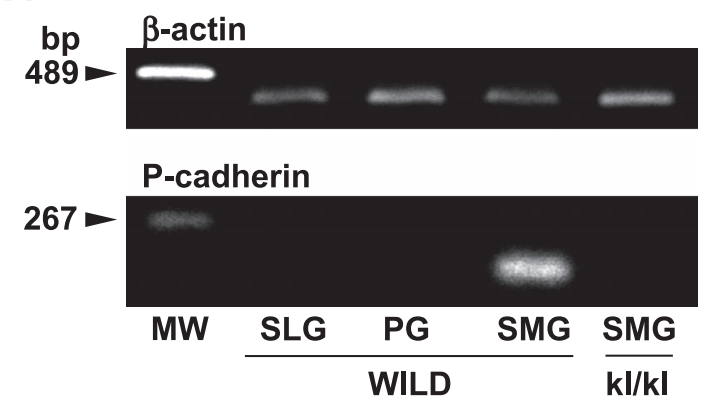

B
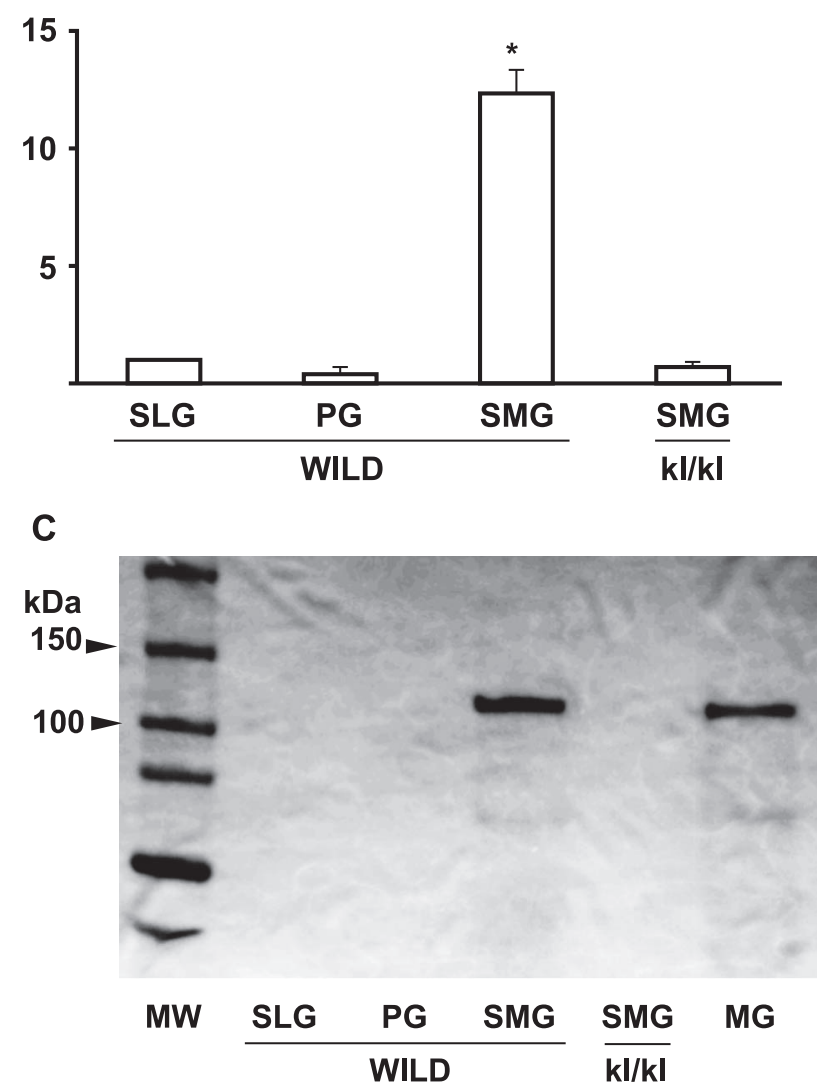

Fig. 8. P-cadherin mRNA and protein production in tissue of mouse salivary glands. (A) RT-PCR analysis: PCR products for $\beta$-actin mRNA are shown in the upper panel and for P-cadherin mRNA in the lower panel. No RT-PCR products of P-cadherin were detected from the tissue of wild type mouse sublingual glands (SLG) and parotid glands $(\mathrm{PG})$, or from the tissue of $\mathrm{kl} / \mathrm{kl}$ mouse submandibular gland (SMG) whereas they were detected from tissue of wild type mouse submandibular gland. MW, molecular weight marker. (B) Real-time PCR analysis. Relative mRNA amounts are expressed in arbitrary units. The P-cadherin mRNA amount in total RNA extracts from tissue is significantly larger in the submandibular gland (SMG) of wild type mice than in the sublingual (SLG) and parotid glands (PG) of wild type mice, and in SMG of $\mathrm{kl} / \mathrm{kl}$ mice. *Statistically significantly difference. (C) Western blot analysis. The P-cadherin protein band $(110 \mathrm{kDa})$ transferred onto the PVDF membrane was detected from the tissue of wild type mouse submandibular gland (SMG) and mammary gland with lactating (MG), but not from wild type mouse sublingual (SLG) and parotid glands (PG), or from SMG of $\mathrm{kl} / \mathrm{kl}$ mice.

\section{Immunohistochemical examination on E-cadherin and $P$-cadherin in mouse salivary glands}

In the mouse submandibular gland, myoepithelial cells around acini and ducts were immunostained with antipodoplanin and anti-E-cadherin in both $\mathrm{kl} / \mathrm{kl}$ and wild type mice (Fig. 5). Epithelial cells of acini and ducts were also stained with anti-E-cadherin at cell-cell contacts where antipodoplanin did not react (Fig. 5). In the parotid, submandibular, and sublingual glands of the wild type mice, reaction products with anti-E-cadherin were found on myoepithelial cells around acini and ducts, and at cell-cell contacts of acinar and duct epithelial cells (Fig. 6). Reaction products with anti-P-cadherin were present in nuclei, and around acini and ducts weakly in both parotid and sublingual glands while granular ducts were filled with strong reaction products with anti-P-cadherin in the submandibular gland (Fig. 6). In all major salivary glands of the $\mathrm{kl} / \mathrm{kl}$ mice, reaction products with anti-E-cadherin were present on myoepithelial cells around acini and ducts, and at cell-cell contacts of epithelial cells of acini and ducts while reaction products with antiP-cadherin were weakly present in nuclei and around acini and ducts (Fig. 7). In submandibular glands of $\mathrm{kl} / \mathrm{kl}$ mice, there were no structures filled with reaction products with anti-P-cadherin like wild type mice because of the lack of granular ducts in $\mathrm{kl} / \mathrm{kl}$ mice.

\section{P-cadherin $\mathrm{mRNA}$ and protein production in mouse salivary glands}

In the RT-PCR analysis, no PCR products were detected from the tissue of the wild type mouse sublingual and parotid glands, or from the tissue of $\mathrm{kl} / \mathrm{kl}$ mouse submandibular glands while it was detected from tissue of the wild type mouse submandibular glands (Fig. 8). In real-time PCR analysis, the P-cadherin mRNA amount in the total RNA extracts from tissue was significantly larger in the submandibular glands of wild type mice than in the sublingual and parotid glands of wild type mice, or in the submandibular glands of $\mathrm{kl} / \mathrm{kl}$ mice (Fig. 8). In western blot analysis, the P-cadherin protein band transferred on the PVDF membrane was detected from the tissue of wild type mouse submandibular gland and mammary gland (Fig. 8).

\section{Discussion}

Myoepithelial cell distribution in $\mathrm{kl} / \mathrm{kl}$ mouse salivary glands

In this study, the sizes of both the body and submandibular glands were significantly smaller in $\mathrm{kl} / \mathrm{kl}$ mice than in wild type mice at seven weeks of age (Fig. 1). It is thought that the growth suppression involved in premature aging affects the size of the acinar lobules [32, 36]. We have recently shown that the salivary gland myoepithelium expresses podoplanin as well as $\alpha$-SMA which is a wellestablished myoepithelial cell marker [4, 14, 19, 20, 38]. In this study, an anti- $\alpha$-SMA reacted to blood vessels without cross reaction to mucous epithelia or muscle cells, anti-Ecadherin reacted to mucous epithelia at cell-cell contacts without cross reaction to muscle cells, and anti-P-cadherin 
reacted to mammary gland epithelia and to milk without cross reaction to muscle cells (Fig. 2), as previously reported $[4,8,14,16,19,20,42,48]$. In the immunostaining for podoplanin and $\alpha$-SMA on submandibular glands, myoepithelial cells which distribute around acini and the basal side of ducts were stained with both anti-podoplanin and anti- $\alpha$ SMA, and anti- $\alpha$-SMA also reacted to the smooth muscle of blood vessel walls (Fig. 3). These findings indicate that the specificities of the immunostaining for podoplanin were successfully achieved on salivary gland myoepithelial cells. The double stained area with anti-podoplanin and anti- $\alpha-$ SMA was smaller and less dense in lobules of $\mathrm{kl} / \mathrm{kl}$ mice than in the wild type mice (Fig. 3). It seems that the systemic metabolism suppression with aging results in a growth suppression of myoepithelial cells which induces atrophy to the major salivary glands (Figs. 1, 3). Further, the inside of acinar cells and the luminal side of ducts reacted with anti$\alpha$-SMA, but not with anti-podoplanin (Fig. 3). The inside of acinar cells and the luminal side of ducts are regions without myoepithelial cells in the salivary glands [38]. Although $\alpha$-SMA is a well-established myoepithelial cell marker, it has been conjectured that anti- $\alpha$-SMA causes cross reaction to the actin universally present in cells $[4,14$, 20]. The specificity of anti-podoplanin to myoepithelium may be better than that of anti- $\alpha$-SMA.

The $\mathrm{kl} / \mathrm{kl}$ mice lacked granular ducts in the submandibular gland [49]. The granular duct is a characteristic structure situated between the intercalated duct and the striated duct in mature rodent submandibular glands, and is controlled by sympathetic innervation $[15,27,28]$. The postnatal conversion of the striated duct into the granular duct occurs under multihormonal regulation $[6,12,28,29$, $31,44]$. The formation of the granular duct begins at four weeks of age. In male mice the granular duct reaches adult status at seven weeks of age whereas in female mice the granular duct distribution at eight weeks of age are at the level of male mice at five weeks of age $[2,6,10,11]$. In the immunostaining for klotho protein on wild type mouse testis and major salivary glands, Sertoli cells were stained by anti-klotho as previously reported $[22,26]$ while acini and ducts other than the granular duct were not stained with anti-klotho in any of the major salivary glands (Fig. 4). Interestingly, only granular duct cells expressed klotho protein on the basal side and $\mathrm{kl} / \mathrm{kl}$ mice showed defects in the development of granular ducts (Figs. 4, 5). Klotho is a calcium regulator which transports $\mathrm{Na}^{+}, \mathrm{K}^{+}$-ATPase from intracellular organelles to the cell surface $[32,36]$. The immunostaining suggests that klotho is a gene responsible for the granular duct development dependent on $\mathrm{Na}^{+}, \mathrm{K}^{+}$ATPase transports in the rodent.

\section{Expression of classical cadherins in salivary glands}

Classical cadherins mediate the calcium-dependent cell-cell adhesion at adherence junctions and combine cytoplasmic $\beta$-catenin which binds to $\alpha$-catenin linking actin filaments. Among classical cadherins, E-cadherin plays a key role mainly at adherence junctions between epithelial cells; P-cadherin plays a role in cell adhesion and has unknown functions in the decidua of the placenta and in mammary gland epithelial cells; $\mathrm{N}$-cadherin functions to form neural tubes and is expressed in the nerve sheath, and also in the intercalated disk of cardiac muscle; and VEcadherin plays a key role in vascular permeability of blood vessels at adherence junctions [7, 16, 21, 40, 47]. In this study, no immunoreaction with either anti-VE-cadherin or anti-N-cadherin was found in myoepithelial cells around acini and ducts (data not shown). The expressions of podoplanin and E-cadherin were found in myoepithelial cells around acini and ducts in the submandibular glands of both $\mathrm{kl} / \mathrm{kl}$ and wild type mice (Fig. 5). Podoplanin links phosphorylated ezrin mediating an anchorage of F-actin to the plasma membrane. Actin filament also links classical cadherins through cytoplasmic $\alpha$ - and $\beta$-catenins $[1,16,18$, $34,37,41,51]$. Therefore, it is thought that podoplanin participates in actin filament networks linking E-cadherins in myoepithelial cells. In the submandibular gland of wild type mice, E-cadherin was also expressed on neighboring epithelial cells of acini and ducts at cell-cell contacts where there were no reaction products with anti-podoplanin (Fig. 5). In parotid and sublingual glands of wild type mice, E-cadherin was expressed on epithelial cells of acini and ducts at cell-cell contacts as well as the submandibular gland (Fig. 6). It is thought that E-cadherin acts as an adhesion molecule and as a mediator of the actin cytoskeleton networks at adherence junctions at cell-cell contacts in salivary gland epithelial cells. The expression of P-cadherin was seen in nuclei of epithelial cells in mammary glands (Fig. 2) and salivary glands (Fig. 6). P-cadherin may play roles other than for adhesion molecules such as in signal transduction [8, 21, 35, 42, 48]. In all major salivary glands of both $\mathrm{kl} / \mathrm{kl}$ and the wild type mice, E-cadherin was expressed on epithelial cells of acini and ducts at cell-cell contacts (Figs. 6, 7), suggesting that the ability to express E-cadherin remains in aging salivary gland epithelia. Interestingly, granular ducts were filled with reaction products with anti-P-cadherin in the wild type mouse submandibular gland (Fig. 6) whereas in the major salivary glands of $\mathrm{kl} / \mathrm{kl}$ mice, there were no structures filled with reaction products with anti-P-cadherin because of lack of granular ducts in $\mathrm{kl} / \mathrm{kl}$ mice (Fig. 7). In the analysis of Pcadherin mRNA and protein expression in the mouse major salivary gland, no RT-PCR products were detected in tissue of wild type mouse sublingual and parotid glands, or in the tissue of $\mathrm{kl} / \mathrm{kl}$ mouse submandibular glands while it was detected in tissue of the wild type mouse submandibular gland. In real-time PCR analysis, the P-cadherin mRNA amount in the total RNA extracts from tissue is significantly larger in the submandibular gland of the wild type mice than in the sublingual and the parotid glands of wild type mice, or in the submandibular gland of $\mathrm{kl} / \mathrm{kl}$ mice (Fig. 8). Further in the western blot analysis, P-cadherin protein of $110 \mathrm{kDa}$ was detected from wild type mouse submandibular gland, and from mammary gland as the positive control $[35,48]$. These findings suggest that the granular duct is an organ 
secreting soluble P-cadherin into the saliva. The well-known function specific to granular ducts is the hormone-dependent production of nerve growth factor and epidermal growth factor in male mice at three weeks of age and in female mice at four weeks of age [11, 13, 50, 52]. It has been reported that $\mathrm{P}$-cadherin is secreted in milk by epithelial cells in lactating mammary glands whereas in non-lactating mammary glands P-cadherin is localized to myoepithelial cells [48]. The P-cadherin and E-cadherin genes are tightly linked on mouse chromosome 8 and soluble E-cadherin plays a role in the epidermal growth factor receptor-mediated activation of both the phosphoinositide- 3 kinase signaling pathways [21, 24]. The soluble P-cadherin secreted in saliva and milk may act as a signaling molecule or a ligand playing roles other than in cell adhesion in rodent intestines.

\section{Acknowledgment}

This work was supported by Grant-in-Aid for Scientific Research (B) 2390345 (principal investigator: Sawa, Y., corresponding author) and Exploratory Research 23659884 (principal investigator: Sawa, T.) from Japan Society for the Promotion of Science.

\section{References}

1. Aberle, H., Schwartz, H. and Kemler, R. (1996) Cadherin-catenin complex: protein interactions and their implications for cadherin function. J. Cell Biochem. 61; 514-523.

2. Amano, O. and Iseki, S. (1998) Occurrence and nuclear localization of cAMP response element-binding protein in the post-natal development of the rat submandibular gland. Histochem. J. 30; 591-601.

3. Belkina, N. V., Liu, Y., Hao, J. J., Karasuyama, H. and Shaw, S. (2009) LOK is a major ERM kinase in resting lymphocytes and regulates cytoskeletal rearrangement through ERM phosphorylation. Proc. Natl. Acad. Sci. US A 106; 4707-4712.

4. Boecker, W. and Buerger, H. (2003) Evidence of progenitor cells of glandular and myoepithelial cell lineages in the human adult female breast epithelium: a new progenitor (adult stem) cell concept. Cell Prolif. 36 Suppl 1; 73-84.

5. Breiteneder-Geleff, S., Matsui, K., Soleiman, A., Meraner, P., Poczewski, H., Kalt, R., Schaffner, G. and Kerjaschki, D. (1997) Podoplanin, novel43-kd membrane protein of glomerular epithelial cells, is down-regulated in puromycin nephrosis. Am. J. Pathol. 151; 1141-1152.

6. Chabot, J. G., Walker, P. and Pelletier, G. (1987) Thyroxine accelerates the differentiation of granular convoluted tubule cells and the appearance of epidermal growth factor in the submandibular gland of the neonatal mouse. A fine-structural immunocytochemical study. Cell Tissue Res. 248; 351-358.

7. Dejana, E., Bazzoni, G. and Lampugnani, M. G. (1999) Vascular endothelial (VE)-cadherin: only an intercellular glue? Exp. Cell Res. 252; 13-19.

8. Gama, A., Paredes, J., Albergaria, A., Gartner, F. and Schmitt, F. (2004) P-cadherin expression in canine mammary tissues. $J$. Comp. Pathol. 130; 13-20.

9. Gautreau, A., Poullet, P., Louvard, D. and Arpin, M. (1999) Ezrin, a plasma membrane-microfilament linker, signals cell survival through the phosphatidylinositol 3-kinase/Akt pathway. Proc. Natl. Acad. Sci. U S A 96; 7300-7305.

10. Gresik, E. W. and Barka, T. (1978) Immunocytochemical local- ization of epidermal growth factor during the postnatal development of the submandibular gland of the mouse. Am. J. Anat. 151; $1-9$.

11. Gresik, E. W. and Azmitia, E. C. (1980) Age related changes in NGF, EGF and protease in the granular convoluted tubules of the mouse submandibular gland. A morphological and immunocytochemical study. J. Gerontol. 35; 520-524.

12. Gresik, E. W., Hosoi, K., Kurihara, K., Maruyama, S. and Ueha, T. (1996) The rodent granular convoluted tubule cell-an update. Eur. J. Morphol. 34; 221-224.

13. Gubits, R. M., Shaw, P. A., Gresik, E. W., Onetti-Muda, A. and Barka, T. (1986) Epidermal growth factor gene expression is regulated differently in mouse kidney and submandibular gland. Endocrinology 119; 1382-1387.

14. Guo, D. C., Pannu, H., Tran-Fadulu, V., Papke, C. L., Yu, R. K., Avidan, N., Bourgeois, S., Estrera, A. L., Safi, H. J., Sparks, E., Amor, D. and Ades, L. (2007) Mutations in smooth muscle alpha actin (ACTA2) lead to thoracic aortic aneurysms and dissections. Nat. Genet. 39; 1488-1493.

15. Gutierrez, M. S., Galera, H., Bullón, P., Hevia, A. and Dorado, M. E. (1990) A morphometric study of the secretory granules of the granular duct in the submaxillary gland of the rat following stimulation with noradrenaline and isoproterenol. Histol. Histopathol. $5 ; 181-186$.

16. Halbleib, J. M. and Nelson, W. J. (2006) Cadherins in development: cell adhesion, sorting, and tissue morphogenesis. Genes Dev. 20; 3199-3214.

17. Hantusch, B., Kalt, R., Krieger, S., Puri, C. and Kerjaschki, D. (2007) Sp1/Sp3 and DNA-methylation contribute to basal transcriptional activation of human podoplanin in MG63 versus Saos-2 osteoblastic cells. BMC Mol. Biol. 8; 20.

18. Harris, T. J. and Tepass, U. (2010) Adherens junctions: from molecules to morphogenesis. Nat. Rev. Mol. Cell Biol. 11; 502514.

19. Hata, M., Ueki, T., Sato, A., Kojima, H. and Sawa, Y. (2008) Expression of podoplanin in the mouse salivary glands. Arch. Oral Biol. 53; 835-841.

20. Hata, M., Amano, I., Tsuruga, E., Kojima, H. and Sawa, Y. (2010) Immunoelectron microscopic study of podoplanin localization in mouse salivary gland myoepithelium. Acta Histochem. Cytochem. 43; 77-82.

21. Hatta, M., Miyatani, S., Copeland, N. G., Gilbert, D. J., Jenkins, N. A. and Takeichi, M. (1991) Genomic organization and chromosomal mapping of the mouse P-cadherin gene. Nucleic Acids Res. 19; 4437-4441.

22. Imai, M., Ishikawa, K., Matsukawa, N., Kida, I., Ohta, J., Ikushima, M., Chihara, Y., Rui, X., Rakugi, H. and Ogihara, T. (2004) Klotho protein activates the PKC pathway in the kidney and testis and suppresses 25-hydroxyvitamin D3 1alphahydroxylase gene expression. Endocrine 25; 229-234.

23. Imaizumi, Y., Amano, I., Tsuruga, E., Kojima, H. and Sawa, Y. (2010) Immunohistochemical examination for the distribution of podoplanin-expressing cells in developing mouse molar tooth germs. Acta Histochem. Cytochem. 43; 115-121.

24. Inge, L. J., Barwe, S. P., D’Ambrosio, J., Gopal, J., Lu, K., Ryazantsev, S., Rajasekaran, S. A. and Rajasekaran, A. K. (2011) Soluble E-cadherin promotes cell survival by activating epidermal growth factor receptor. Exp. Cell Res. 317; 838-848.

25. Iwasawa, K., Kameyama, T., Ishikawa, H. and Sawa, Y. (2008) Induction of ICAM-1 and VCAM-1 on the mouse lingual lymphatic endothelium with TNF- $\alpha$. Acta Histochem. Cytochem. 41; $115-120$.

26. Kamitani, A., Yamada, H., Kinuta, M., Watanabe, M., Li, S. A., Matsukawa, T., McNiven, M., Kumon, H. and Takei, K. (2002) Distribution of dynamins in testis and their possible relation to spermatogenesis. Biochem. Biophys. Res. Commun. 294; 261267. 
27. Kanno, T., Asada, N., Yanase, H., Iwanaga, T., Ozaki, T., Nishikawa, Y., Iguchi, K., Mochizuki, T., Hoshino, M. and Yanaihara, N. (1999) Salivary secretion of highly concentrated chromogranin a in response to noradrenaline and acetylcholine in isolated and perfused rat submandibular glands. Exp. Physiol. 84; 1073-1083.

28. Keattikunpairoj, S., Wakayama, T., Yamamoto, M., Nakaya, M A., Nakata, H., Hipkaeo, W., Sakulsak, N. and Iseki, S. (2009) Expression of cAMP response element-binding protein in the duct system of the mouse submandibular gland. Histochem. Cell Biol. 132; 647-657.

29. Kim, J., Amano, O., Wakayama, T., Takahagi, H. and Iseki, S. (2001) The role of cyclic AMP response element-binding protein in testosterone-induced differentiation of granular convoluted tubule cells in the rat submandibular gland. Arch. Oral Biol. 46; 495-507

30. Koop, K., Eikmans, M., Wehland, M., Baelde, H., Ijpelaar, D., Kreutz, R., Kawachi, H., Kerjaschki, D., de Heer, E. and Bruijn, J. A. (2008) Selective loss of podoplanin protein expression accompanies proteinuria and precedes alterations in podocyte morphology in a spontaneous proteinuric rat model. Am. J. Pathol. 173; 315-326.

31. Kurabuchi, S. and Hosoi, K. (2009) Immunocytochemical study of granular duct cells with a hormonally enhanced granular cell phenotype in the mouse parotid gland. Odontology 97; 57-61.

32. Kuro-o, M. (2010) Klotho. Pflugers Arch. 459; 333-343.

33. Lan, M., Kojima, T., Murata, M., Osanai, M., Takano, K., Chiba, H. and Sawada, N. (2006) Phosphorylation of ezrin enhances microvillus length via a p38 MAP-kinase pathway in an immortalized mouse hepatic cell line. Exp. Cell Res. 312; 111-120.

34. Lien, W. H., Klezovitch, O. and Vasioukhin, V. (2006) Cadherincatenin proteins in vertebrate development. Curr. Opin. Cell Biol. $18 ; 499-506$

35. Lo Muzio, L., Pannone, G., Mignogna, M. D., Staibano, S., Mariggio, M. A., Rubini, C., Procaccini, M., Dolci, M., Bufo, P., De Rosa, G. and Piattelli, A. (2004) P-cadherin expression predicts clinical outcome in oral squamous cell carcinomas. Histol. Histopathol. 19; 1089-1099.

36. Manya, H., Akasaka-Manya, K. and Endo, T. (2010) Klotho protein deficiency and aging. Geriatr. Gerontol. Int. 10 Suppl 1; S80-87.

37. Martín-Villar, E., Megías, D., Castel, S., Yurrita, M. M., Vilaró, S. and Quintanilla, M. (2006) Podoplanin binds ERM proteins to activate RhoA and promote epithelial-mesenchymal transition. J. Cell Sci. 119; 4541-4553.

38. Nagato, T., Yoshida, H., Yoshida, A. and Uehara, Y. (1980) A scanning electron microscope study of myoepithelial cells in exocrine glands. Cell Tissue Res. 209; 1-10.

39. Noda, Y., Amano, I., Hata, M., Kojima, H. and Sawa, Y. (2010) Immunohistochemical examination of the distribution of cells expressed lymphatic endothelial marker podoplanin and LYVE-1 in the mouse tongue tissue. Acta Histochem. Cytochem. 43; 6168 .

40. Nose, A. and Takeichi, M. (1986) A novel cadherin cell adhesion molecule: its expression patterns associated with implantation and organogenesis of mouse embryos. J. Cell Biol. 103; 26492658.

41. Pujuguet, P., Del Maestro, L., Gautreau, A., Louvard, D. and Arpin, M. (2003) Ezrin regulates E-cadherin-dependent adherens junction assembly through Rac1 activation. Mol. Biol. Cell. 14; 2181-2191

42. Radice, G. L., Ferreira-Cornwell, M. C., Robinson, S. D., Rayburn, H., Chodosh, L. A., Takeichi, M. and Hynes, R. O. (1997) Precocious mammary gland development in P-cadherindeficient mice. J. Cell Biol. 139; 1025-1032.

43. Raica, M., Cimpean, A. M. and Ribatti, D. (2008) The role of podoplanin in tumor progression and metastasis. Anticancer Res. 28; 2997-3006.

44. Sato, S., Maruyama, S. and Azuma, T. (1981) Androgenic action of glucocorticoids on the granular ducts of mouse submandibular glands. J. Endocrinol. 89; 267-274.

45. Sawa, Y., Iwasawa, K. and Ishikawa, H. (2008) Expression of podoplanin in the mouse tooth germ and apical bud cells. Acta Histochem. Cytochem. 41;121-126.

46. Schacht, V., Ramirez, M. I., Hong, Y. K., Hirakawa, S., Feng, D., Harvey, N., Williams, M., Dvorak, A. M., Dvorak, H. F., Oliver, G. and Detmar, M. (2003) T1 $\alpha /$ podoplanin deficiency disrupts normal lymphatic vasculature formation and causes lymphedema. EMBO J. 22; 3546-3556.

47. Shimoyama, Y., Yoshida, T., Terada, M., Shimosato, Y., Abe, O. and Hirohashi, S. (1989) Molecular cloning of a human $\mathrm{Ca}(2+)-$ dependent cell-cell adhesion molecule homologous to mouse placental cadherin: its low expression in human placental tissues. J. Cell Biol. 109; 1787-1794.

48. Soler, A. P., Russo, J., Russo, I. H. and Knudsen, K. A. (2002) Soluble fragment of P-cadherin adhesion protein found in human milk. J. Cell Biochem. 85; 180-184.

49. Suzuki, H., Amizuka, N., Noda, M., Amano, O. and Maeda, T. (2006) Histological and immunohistochemical changes in the submandibular gland in klotho-deficient mice. Arch. Histol. Cytol. 69; 119-128.

50. Watson, A. Y., Anderson, J. K., Siminoski, K., Mole, J. E. and Murphy, R. A. (1985) Cellular and subcellular colocalization of nerve growth factor and epidermal growth factor in mouse submandibular glands. Anat. Rec. 213; 365-376.

51. Wicki, A., Lehembre, F., Wick, N., Hantusch, B., Kerjaschki, D. and Christofori, G. (2006) Tumor invasion in the absence of epithelial-mesenchymal transition: podoplanin-mediated remodeling of the actin cytoskeleton. Cancer Cell 9; 261-272.

52. Young, W. G., Ramirez-Yanez, G. O., Daley, T. J., Smid, J. R., Coshigano, K. T., Kopchick, J. J. and Waters, M. J. (2004) Growth hormone and epidermal growth factor in salivary glands of giant and dwarf transgenic mice. J. Histochem. Cytochem. 52; $1191-1197$.

This is an open access article distributed under the Creative Commons Attribution License, which permits unrestricted use, distribution, and reproduction in any medium, provided the original work is properly cited 